\title{
WORKING TOWARDS EQUITY
}

\author{
Disability Rights Activism and Employment \\ in Late Twentieth-Century Canada
}

In Working towards Equity, Dustin Galer argues that paid work significantly shaped the experience of disability during the late twentieth century. By investigating and analysing archival records, personal collections, government publications, and a series of interviews, Galer demonstrates how demands for greater access to gainful employment from disabled people stimulated the development of a new discourse of disability in Canada.

Family advocates helped people living in institutions move out into the community as rehabilitation professionals played an increasingly critical role in the lives of working-age adults with disabilities. Meanwhile, civil rights activists crafted a new consumer-led vision of social and economic integration. Employment was, and remains, a central component in disabled peoples' efforts to become productive, autonomous, and financially secure members of Canadian society. Working towards Equity offers new in-depth analysis on rights activism as it relates to employment, sheltered workshops, deinstitutionalization, and labour markets in the contemporary context in Canada.

DUSTIN GALER received his PhD in history from the University of Toronto. He is the founder of MyHistorian (www.myhistorian.ca) where he works as a personal historian. 
This page intentionally left blank 


\section{Working towards Equity}

Disability Rights Activism

and Employment in Late

Twentieth-Century Canada

\section{DUSTIN GALER}


(C) University of Toronto Press 2018

Toronto Buffalo London

utorontopress.com

Printed in Canada

ISBN 978-1-4875-0131-0 (cloth) ISBN 978-1-4875-2130-1 (paper)

(2) Printed on acid-free, $100 \%$ post-consumer recycled paper with vegetablebased inks.

\section{Library and Archives Canada Cataloguing in Publication}

Galer, Dustin, 1983-, author

Working towards equity: disability rights activism and employment in late twentieth-century Canada/Dustin Galer.

Includes bibliographical references and index.

ISBN 978-1-4875-0131-0 (hardcover) ISBN 978-1-4875-2130-1 (softcover)

1. People with disabilities - Civil rights - Canada - History - 20th century.

2. People with disabilities - Legal status, laws, etc. - Canada - History 20th century. 3. People with disabilities - Employment - Canada - History 20th century. I. Title.
HV1559.C3G36 2018
362.40971
C2017-907099-1

This book has been published with the help of a grant from the Federation for the Humanities and Social Sciences, through the Awards to Scholarly Publications Program, using funds provided by the Social Sciences and Humanities Research Council of Canada.

University of Toronto Press acknowledges the financial assistance to its publishing program of the Canada Council for the Arts and the Ontario Arts Council, an agency of the Government of Ontario.

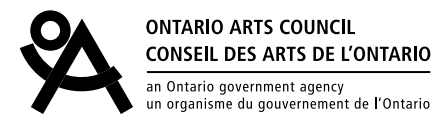


To my family 
This page intentionally left blank 